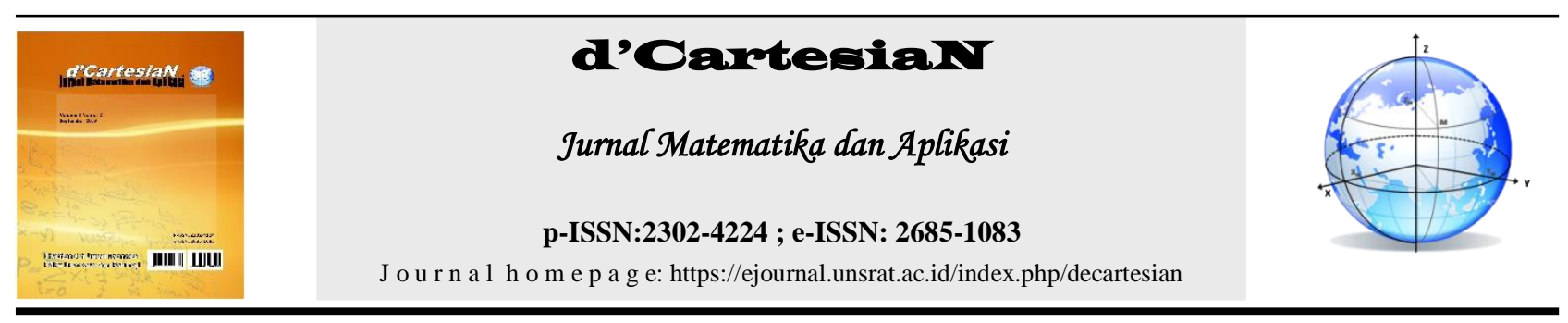

\title{
Analisis Rantai Markov terhadap Pola Perpindahan Konsumen Pasar Swalayan di Kota Manado dengan Penilaian Pasar Swalayan menggunakan Metode Simple Additive Weight (SAW)
}

\author{
Riri A. Suratinoyo', Fernando D. Pongoh ${ }^{1}$, Yohanes A.R. Langi 1* \\ ${ }^{1}$ Jurusan Matematika, Fakultas Matematika dan Ilmu Pengetahuan Alam, Universitas Sam Ratulangi Manado, Indonesia \\ *Corressponding author : yarlangi@unsrat.ac.id
}

\begin{abstract}
A B S T R A K
Perpindahan konsumen pasar swalayan sangat berpengaruh di dunia industri. Konsumen memiliki peran penting bagi industri tersebut, sehingga sangat penting untuk mengetahui pola perpindahan konsumen, mengacu pada beberapa penelitian sebelumnya, untuk mengetahui pola perpindahan konsumen harus menggunakan Analisis Rantai Markov. Rantai Markov sendiri memiliki sifat bahwa kejadian di masa lalu tidak mempengaruhi kejadian di masa yang akan datang apabila kejadian saat ini diketahui. Setelah mengetahui pola perpindahan konsumen, langkah selanjutnya adalah melakukan penilaian pasar swalayan menggunakan metode Simple Additive Weight yang lebih dikenal dengan metode penjumlahan terbobot. Kedua metode ini sangat baik dalam penelitian ini, dengan menggunakan analisis Rantai Markov didapati bahwa Golden merupakan pasar swalayan paling diminati oleh konsumen karena memiliki paling banyak konsumen yang berbelanja dalam kurun waktu lama. Sedangkan menggunakan metode Simple Additive Weight didapati bahwa Freshmart merupakan pasar swalayan terbaik karena memenuhi 6 kriteria yang telah di tentukan yakni Harga, Kelengkapan Kebutuhan, Promosi, Lokasi, Kenyamanan Tempat dan Pelayanan Karyawan.
\end{abstract}

\section{INFO ARTIKEL}

Diterima : 12 Juli 2019

Diterima setelah revisi : 23 Juli 2019

Tersedia online : 25 Juli 2019

\section{Kata Kunci:}

Rantai Markov

Perpindahan Konsumen

Pasar Swalayan

Simple Additive Weight (SAW)

\begin{abstract}
A B S T RACT
Consumer transfer of supermarkets is very influential in the industrial world. Consumers have an important role for the industry, so it is very important to know the pattern of consumer movements, referring to several previous studies, to find out the patterns of consumer movement must use Markov Chain Analysis. The Markov chain itself has the nature that past events do not affect future events if the current event is known. After knowing the pattern of consumer movement, the next step is to do a supermarket evaluation using the Simple Additive Weight method, better known as the weighted addition method. Both of these methods are very good in this study, using Markov Chain analysis found that Golden is the most preferred supermarket by consumers because it has the most consumers who shop for a long time. While using the Simple Additive Weight method, it was found that Freshmart is the best supermarket because it fulfills 6 criteria that have been determined, namely Price, Completeness of Needs, Promotion, Location, Comfort Place and Service of Employees.
\end{abstract}

\author{
ARTICLE INFO : \\ Received : 12 July 2019 \\ Received After Revision : 23 July 2019 \\ Available online : 25 July 2019
}

\section{Keywords:}

Markov Chain

Consumer Transfer

Supermarket

Simple Additive Weight (SAW)

\section{PENDAHULUAN}

Pasar swalayan dapat didefinisikan sebagai tempat perbelanjaan berbentuk toko yang menjual berbagai macam makanan, minuman, serta bermacam-macam perlengkapan rumah tangga. Pada umumnya pasar swalayan menempati ruang yang luas, dan karena ragam barang yang dijajakan, pasar itu dikenal dengan supermarket. Keinginan konsumen untuk memenuhi kebutuhan sehari-hari menjadi satu alasan yang kuat untuk membeli produk atau barang yang dibutuhkan dalam kehidupan sehari-hari.

Oleh karena itu, perlu adanya prediksi market share agar tingkat penjualan dapat optimal. Market share (pangsa Pasar) dapat diartikan sebagai bagian pasar yang dikuasai oleh suatu perusahaan, atau presentasi penjualan suatu perusahaan terhadap total penjualan para pesaing terbesarnya pada waktu dan tempat tertentu. Besarnya pangsa pasar setiap saat akan berubah sesuai dengan perubahan selera konsumen, atau berpindahnya minat konsumen dari suatu produk ke produk lain. [1]

Untuk memprediksi pangsa pasar diwaktu yang akan datang adalah dengan menggunakan analisis Rantai Markov. Analisis Rantai Markov merupakan sebuah metode dalam menganalisis perilaku saat ini dari beberapa variabel, dengan tujuan untuk memprediksi perilaku konsumen terhadap perpindahan pemilihan pasar swalayan. Selain itu, mengetahui kualitas dari perusahaan itu sendiri juga sangat penting, untuk itu dibutuhkan suatu proses otomatitasi dengan menggunakan teknologi. Sistem Pendukung Keputusan 
merupakan sistem yang dapat membantu para pengambil keputusan dengan memanfaatkan komputer dalam pengambilan keputusan. Sistem yang dibuat menggunakan metode Simple Additive Weight (SAW). Metode SAW sering juga dikenal dengan istilah metode penjumlahan terbobot.

Analisis Rantai Markov saat ini banyak digunakan sebagaimana penelitian sebelumnya oleh Allo dkk dalam Mengetahui Peluang Perpindahan Merek Kartu Seluler Pra Bayar GSM (2012). Nurjana dkk dalam Pemilihan Minat Masuk Siswa SMA Ke Universitas di Indonesia (2016). Masuku dkk dalam Memprediksi Perpindahan Konsumen Maskapai Penerbangan Rute ManadoJakarta (2018). [2] [3] [4]

Selain itu, mengetahui kualitas dari perusahaan itu sendiri juga sangat penting, untuk itu dibutuhkan suatu proses otomatitasi dengan menggunakan teknologi. Kebutuhan sebuah sistem yang berbasis komputer dirasa sangat perlu guna memenuhi tuntutan akan kebutuhan informasi. Sistem yang dimaksud adalah Sistem pendukung keputusan (SPK). Sistem Pendukung Keputusan merupakan sistem yang dapat membantu para pengambil keputusan dengan memanfaatkan komputer dalam pengambilan keputusan. Sistem yang dibuat menggunakan metode Simple Additive Weight (SAW). Metode SAW sering juga dikenal dengan istilah metode penjumlahan terbobot.

Metode Sistem Pendukung Keputusan (SPK) juga pernah diteliti oleh Pareda dkk (2018) dengan judul Sistem pendukung keputusan pemilihan karyawan teladan di PT ANEKA Tambang (ANTAM) TBK unit bisnis pertambangan buli menggunakan Metode Simple Additive Weight (SAW), dan Ontah dkk (2014) dengan judul Sistem Pendukung keputusan dalam memetakan wilayah risiko banjir menggunakan Fuzzy Multi Criteria Decision making. [5] [6]

\section{Proses Stokastik}

Proses stokastik $\mathrm{X}=\{\mathrm{X}(\mathrm{t}), \mathrm{t} \in \mathrm{T}\}$ adalah suatu koleksi (gugus,himpunan, atau kumpulan) dari peubah acak (random variable) yang memetakkan suatu ruang contoh (sample space) $\Omega$ ke suatu ruang state (state space) $\mathrm{S}$. Untuk setiap $t$ pada gugus (himpunan) indeks $\mathrm{T}, \mathrm{X}(t)$ adalah suatu peubah acak. Dimana $t$ sebagai waktu (meskipun dalam berbagai penerapannya t tidak selalu menyatakan waktu), dan $\mathrm{X}(t)$ sebagai state (keadaan) dari proses pada waktu $t$.

\section{Analisis Rantai Markov}

Terdapat suatu peluang tetap $P_{i j}$ yang bersifat bebas terhadap waktu maka berlaku

$P\left\{X_{t=1}=j \mid X_{0}=i_{0}, \ldots, X_{t-1}=i_{t-1}, X_{t}=i\right\}=$

$p\left\{X_{t+1}=j \mid X_{t}=i\right\}$

Dimana

$$
\begin{aligned}
& i=\text { state } \mathrm{ke}-i \\
& j=\text { state } \mathrm{ke}-j \\
& \mathrm{t}=\text { waktu }
\end{aligned}
$$

$i_{0}, \ldots, i_{t-1}, i, j$ dan semua $t \geq 0$.

Persamaan (1) dinamakan rantai markov, sebagai penghargaan terhadap A.A. Markov (1856-1922) yang untuk pertama kalinya meneliti proses stokastik yang mempunyai sifat khusus tersebut.

\section{Peluang transisi $n-S t e p$}

Peluang transisi $n$-step $P_{i j}^{(n)}$ adalah peluang bersyarat suatu sistem yang berada pada state $i$ akan berada pada state $j$ setelah proses mengalami $n$ transisi. [7]

$$
\begin{aligned}
& \text { Jadi, } \\
& P_{i j}^{(n)}=X n=j \mid X_{0}=i, i, j \in\{0,1,2, \ldots\}
\end{aligned}
$$

Untuk setiap $n=1,2, \ldots$ Tentunya $P_{i j}^{(1)}=P_{\mathrm{i}, \mathrm{j}}$.

Nilai $p_{\mathrm{i}, \mathrm{j}}$ diatas menyatakan bahwa, jika proses tersebut berada pada state $i$, maka berikutnya akan beralih ke state $j$. Karena nilai peluang adalah tak negatif dan karena proses tersebut harus mengalami transisi ke suatu state, maka:

$$
\begin{array}{ll}
\text { i. } & P_{i, j} \geq 0, \text { untuk semua } i, \mathrm{j} \in\{0,1,2, \ldots\} \\
\text { ii. } & \sum_{j=0}^{\infty} p_{i, j}=1, \text { untuk semua } i \in\{0,1,2, \ldots\}
\end{array}
$$

\section{Peluang Steady State}

Suatu state disebut berulang positif (positive recurrent) jika state tersebut adalah berulang (recurrent). Sebaran steady state sering juga disebut sebaran stasioner atau sebaran setimbang (equilibrium distribution) dari proses rantai markov.

\section{Metode Simple Additive Weight (SAW)}

Simple Additive Weight (SAW) sering juga dikenal dengan istilah metode penjumlahan terbobot. Konsep dasar metode Simple Additive Weight (SAW) adalah mencari penjumlahan terbobot dari rating kinerja pada setiap alternatif pada semua atribut. Metode Simple Additive Weight (SAW) merupakan metode yang banyak digunakan dalam pengambilan keputusan yang memiliki banyak atribut. [8]

\section{METODE PENELITIAN}

Penelitian ini dilaksanakan selama bulan Desember 2018 sampai Februari 2019, mulai dari penyusunan proposal, pengambilan data hingga pengolahan data. Pengolahan data dilakukan di Laboratorium Statistika Program Studi Matematika Fakultas MIPA Universitas Sam Ratulangi.

Dalam penelitian ini data yang digunakan adalah data primer yang merupakan hasil penilaian 100 konsumen terhadap pasar swalayan yang ada di kota Manado.

Penilaian konsumen ini diambil dari 100 kuesioner yang terbagi secara acak untuk tiap pelanggan yang pernah berbelanja kebutuhan pokok non pakaian di 6 tempat, yakni Golden, Jumbo, Gelael, Freshmart, Multimart, dan Hypermart.

Langkah-langkah dalam menganalisis data adalah sebagai berikut :

1) Pengumpulan data menggunakan metode Purposive Random Sampling. Dimana pengambilan sampel secara sengaja tetapi berdasarkan kriteria. Kriteria yang dimaksud terdapat dalam tabel 1.

2) Membuat tabel perpindahan konsumen pasar swalayan.

3) Klasifikasi pasar swalayan dalam matriks peluang transisi dari analisis rantai markov.

4) Menentukan pasar swalayan terbaik menggunakan metode SAW berdasarkan penilaian konsumen. 
Riri A. Suratinoyo, Fernando D. Pongoh, Yohanes A.R. Langi

d'Cartesian : Jurnal Matematika dan Aplikasi, Vol. 8 No. 2 (September 2019): 76-79

Tabel 1. Kriteria penelitian pada pasar swalayan di kota Manado

\begin{tabular}{cl}
\hline No. & Kriteria Penilaian Pasar Swalayan \\
\hline $\mathbf{1}$ & Lokasi \\
$\mathbf{2}$ & Kenyamanan Tempat \\
3 & Kelengkapan Kebutuhan \\
4 & Pelayanan Karyawan \\
5 & Harga \\
6 & Promosi \\
\hline
\end{tabular}

\section{HASIL DAN PEMBAHASAN}

\section{Pasar Swalayan yang dikunjungi}

Dari Kuesioner yang terkumpul diperoleh hasil bahwa pasar swalayan yang dikunjungi oleh responden adalah seperti pada tabel 2.

Tabel 2. Jumlah Konsumen Masing-masing Pasar Swalayan.

\begin{tabular}{llcc}
\hline No. & $\begin{array}{c}\text { Nama Pasar } \\
\text { Swalayan }\end{array}$ & $\begin{array}{c}\text { Jumlah } \\
\text { Konsumen } \\
\text { Sebelum }\end{array}$ & $\begin{array}{c}\text { Presentase } \\
(\%)\end{array}$ \\
\hline 1 & Golden & 30 & 30 \\
2 & Jumbo & 16 & 16 \\
3 & Gelael & 7 & 7 \\
4 & Freshmart & 20 & 20 \\
5 & Multimart & 21 & 21 \\
6 & Hypermart & 6 & 6 \\
& Jumlah & 100 & 100 \\
\hline
\end{tabular}

\section{Perpindahan Konsumen Pasar Swalayan}

Untuk mengetahui lebih jelas tentang perpindahan konsumen satu pasar swalayan ke pasar swalayan lainnya, dapat dilihat pada tabel 3 .

Tabel 3. Jumlah Konsumen Pasar Swalayan Sebelumnya dan Sekarang

\begin{tabular}{cccccc}
\hline No. & $\begin{array}{c}\text { Nama } \\
\text { Pasar } \\
\text { Swalayan }\end{array}$ & $\begin{array}{c}\text { Jumlah } \\
\text { Konsumen } \\
\text { Sebelum }\end{array}$ & $\begin{array}{c}\text { Perolehan } \\
\text { (orang) }\end{array}$ & $\begin{array}{c}\text { Kehilangan } \\
\text { (orang) }\end{array}$ & $\begin{array}{c}\text { Jumlah } \\
\text { Konsumen } \\
\text { Sekarang }\end{array}$ \\
\hline 1 & Golden & 30 & 0 & 3 & 27 \\
2 & Jumbo & 16 & 4 & 0 & 20 \\
3 & Gelael & 7 & 0 & 0 & 7 \\
4 & Freshmart & 20 & 4 & 0 & 24 \\
5 & Multimart & 21 & 0 & 7 & 14 \\
6 & Hypermart & 6 & 2 & 0 & 8 \\
& Jumlah & 100 & 100 & 10 & 10 \\
\hline
\end{tabular}

Berdasarkan tabel 3, maka dapat disimpulkan bahwa tiap pasar swalayan mengalami perolehan dan kehilangan konsumen. Tabel 4 memperlihatkan pola perpindahan konsumen keenam pasar swalayan tersebut. Dimana masing-masing konsumen pasar swalayan berpindah ke pasar swalayan yang lain.
Tabel 4. Pola Perpindahan Konsumen Pasar Swalayan

\begin{tabular}{lccccccc}
\hline \multicolumn{7}{c}{ Ke Pasar Swalayan } \\
\hline $\begin{array}{c}\text { Nama } \\
\text { Pasar } \\
\text { Swalayan }\end{array}$ & Golden & Jumbo & Gelael & $\begin{array}{l}\text { Fresh } \\
\text { mart }\end{array}$ & $\begin{array}{l}\text { Multi } \\
\text { mart }\end{array}$ & $\begin{array}{l}\text { Hyper } \\
\text { mart }\end{array}$ & $\begin{array}{l}\text { Respon. } \\
\text { Sebelum }\end{array}$ \\
\hline Golden & 17 & 1 & 2 & 5 & 4 & 1 & 30 \\
Jumbo & 0 & 11 & 1 & 2 & 1 & 1 & 16 \\
Gelael & 2 & 1 & 1 & 1 & 1 & 1 & 7 \\
Freshmart & 1 & 1 & 1 & 15 & 1 & 1 & 20 \\
Multimart & 6 & 6 & 1 & 1 & 7 & 0 & 21 \\
Hypermart & 1 & 0 & 1 & 0 & 0 & 4 & 6 \\
Respon. & 27 & 20 & 7 & 24 & 14 & 8 & 100 \\
Saatini & & & & & & & \\
\hline
\end{tabular}

Tabel 4 menunjukan bahwa masing-masing pasar swalayan mengalami perpindahan konsumen. Dimana angka o menunjukan bahwa tidak ada perpindahan konsumen pasar swalayan.

Berdasarkan Tabel 4, maka dapat ditentukan Tabel Peluang Transisi (P) seperti yang disajikan pada tabel 5 .

Tabel 5. Peluang Transisi (P)

\begin{tabular}{ccccccc}
\hline & \multicolumn{7}{c}{ Ke Pasar Swalayan } \\
$\begin{array}{c}\text { Dari Pasar } \\
\text { Swalayan }\end{array}$ & Golden & Jumbo & Gelael & Freshmart & Multimart & $\begin{array}{c}\text { Hyper } \\
\text { mart }\end{array}$ \\
\cline { 2 - 7 } & & & & & 0.13 & 0.03 \\
Golden & 0.57 & 0.03 & 0.07 & 0.17 & 0.06 & 0.06 \\
Jumbo & 0 & 0.7 & 0.06 & 0.12 & 0.14 & 0.14 \\
Gelael & 0.3 & 0.14 & 0.14 & 0.14 & 0.05 & 0.05 \\
Freshmart & 0.05 & 0.05 & 0.05 & 0.75 & 0.33 & 0 \\
Multimart & 0.29 & 0.28 & 0.05 & 0.05 & 0 & 0.66 \\
Hypermart & 0.17 & 0 & 0.17 & 0 & 0.14 & 0.08 \\
Market & 0.27 & 0.2 & 0.07 & 0.24 & & \\
Share & & & & & &
\end{tabular}

Dan berdasarkan tabel peluang transisi, maka market share dapat memprediksi konsumen masingmasing pasar swalayan seperti pada tabel 6 .

Tabel 6. Prediksi Konsumen Masing-masing Pasar Swalayan di Kota Manado dari Tahun 2018 sampai 2020.

\begin{tabular}{lcccccc}
\hline \multirow{2}{*}{ Tahun } & \multicolumn{5}{c}{ Presentase Pasar Swalayan } \\
\cline { 2 - 7 } & Golden & Jumbo & Gelael & Freshmart & Multimart & Hypermart \\
\hline 2018 & $24 \%$ & $21 \%$ & $1 \%$ & $27 \%$ & $11 \%$ & $1 \%$ \\
2019 & $22 \%$ & $21 \%$ & $1 \%$ & $28 \%$ & $10 \%$ & $10 \%$ \\
2020 & $21 \%$ & $20 \%$ & $1 \%$ & $29 \%$ & $10 \%$ & $11 \%$ \\
\hline
\end{tabular}

\section{Metode Simple Additive Weight}

Untuk melakukan pengambilan keputusan ini terdapat objek yang akan dibahas yaitu kriteria dan alternatif. Berikut adalah kriteria-kriteria yang dibutuhkan untuk mengukur dan menilai pasar swalayan mana yang menjadi pasar swalayan terbaik menurut penilaian konsumen, antara lain :
a. Harga
$=20$
b. Kelengkapan Kebutuhan
$=20$
c. Promosi
$=15$
d. Lokasi
$=20$
e. Kenyamanan Tempat
$=15$
f. Pelayanan Karyawan
$=10$

Berdasarkan kriteria dan bobot di atas, maka dapat ditentukan pasar swalayan terbaik sesuai dengan 
penilain konsumen. Untuk masing-masing pasar swalayan, dituliskan dengan $\mathrm{R}$. dimana $\mathrm{R}_{1}$ untuk Golden, $\mathrm{R}_{2}$ untuk Jumbo, $\mathrm{R}_{3}$ untuk Gelael, $\mathrm{R}_{4}$ untuk Freshmart, $\mathrm{R}_{5}$ untuk Multimart, dan $\mathrm{R}_{6}$ untuk Hypermart. Seperti pada tabel 7 .

Tabel 7. Penentuan Rangking

\begin{tabular}{cccc}
\hline $\begin{array}{c}\text { Alternatif } \\
\text { (Pasar } \\
\text { Swalayan) }\end{array}$ & Nilai & $\begin{array}{c}\text { Presentase } \\
(\%)\end{array}$ & Rangking \\
\hline$R_{4}$ & 59,72807018 & $5972,81 \%$ & 1 \\
$R_{6}$ & 58,09649123 & $5809,65 \%$ & 2 \\
$R_{1}$ & 57,16666667 & $5716,67 \%$ & 3 \\
$R_{5}$ & 53,65629984 & $5365,63 \%$ & 4 \\
$R_{2}$ & 42,91068581 & $4291,07 \%$ & 5 \\
$R_{3}$ & 39,99122807 & $3999,12 \%$ & 6 \\
\hline
\end{tabular}

\section{Penutup}

\section{Kesimpulan}

1. Berdasarkan hasil analisis Rantai markov dapat diketahui bahwa faktor perpindahan konsumen suatu pasar swalayan dipengaruhi oleh aspek penilaian konsumen yakni lokasi, kenyamanan tempat, kelengkapan kebutuhan, pelayanan karyawan, harga dan promosi.

2. Tahun 2018 : Golden 24\%, Jumbo 21\%, Gelael 1\%, Freshmart 27\%, Multimart 11\%, Hypermart 1\%.

Tahun 2019: Golden 22\%, Jumbo 21\%, Gelael 1\%, Freshmart 28\%, Multimart 10\%, Hypermart 10\%.

Tahun 2020 : Golden 21\%, Jumbo 20\%, Gelael 1\%, Freshmart 29\%, Multimart 10\%, Hypermart 11\%.

3. Dari perhitungan dengan menggunakan metode Simple Additive Weight (SAW), dengan acuan kriteria harga, kelengkapan kebutuhan, promosi, lokasi, kenyamanan tempat dan pelayanan karyawan maka terpilih Freshmart yang menjadi pasar swalayan terbaik menurut penilaian konsumen. Dan dari hasil analisis perhitungan semua alternatif didapati kesimpulan bahwa untuk menjadi menjadi pasar swalayan terbaik tidak hanya dinilai dari satu kriteria, melainkan harus memiliki keenam kriteria tersebut.

\section{Saran}

Dalam penelitian skripsi selanjutnya dilakukan pembatasan responden, yakni yang mengisi kuesioner adalah orang yang berbelanja kebutuhan pokok nonpakaian dirumah. Juga diharapkan melalui skripsi ini pasar swalayan yang terkait mampu meningkatkan kualitas perusahaan sehingga mampu menarik minat konsumen.

\section{REFERENSI}

[1] Djan, I., dan R. Ruvendi. 2006. Prediksi perpindahan penggunaan merek handphone di kalangan mahasiswa (studi kasus pada mahasiswa STIE Binaniaga). Jurnal Ilmiah Binaniaga 2(1)

[2] Allo, D. G., D. Hatidja., dan M. Paendong. 2012. Analisis Rantai Markov untuk mengetahui peluang perpindahan merek kartu seluler Pra Bayar GSM.

\section{Jurnal MIPA Unsrat ONLINE, 2(1):17-22}

[3] Nurjana, S., M. Paendong., dan Y. Langi. 2016. Penerapan Rantai Markov dalam pemilihan minat masuk siswa SMA ke Universitas di Indonesia. Jurnal d'Cartesian 5(1):50-56

[4] Masuku, F., Y. Langi., dan C. E. Mongi. 2018. Analisis Rantai Markov untuk memprediksi perpindahan konsumen maskapai penerbangan rute Manado-Jakarta. Jurnal Ilmiah Sains 18(2):1530

[5] Pareda, S., C. E. Mongi., dan C. E. J. C. Montolalu. 2018. Sistem pendukung keputusan pemilihan karyawan teladan di PT ANEKA Tambang (ANTAM) TBK unit bisnis pertambangan buli menggunakan Metode Simple Additive Weight (SAW). Jurnal d'Cartesian 8(1):5-7

[6] Ontah, G. M., W. Weku., dan A. J. Rindengan. 2014. Sistem Pendukung keputusan dalam memetakan wilayah risiko banjir menggunakan Fuzzy Multi Criteria Decision making. Jurnal d'Cartesian 3(2) : 1-30

[7] Hiller, F. S., and G. J. Lieberman. 2008. Introduction to operation research eight edition jilid 2. Penerbit Andi. Jogjakarta.

[8] Nofriansyah. 2014. Konsep data Mining Vs Sistem Pendukung Keputusan. Deepublish : Yogyakarta.

Riri A. Suratinoyo (riri.suratinoyo01@gmail.com)

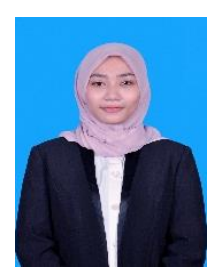
Lahir di Kwandang, Gorontalo Utara pada tanggal 9 Desember 1997. Menempuh pendidikan tinggi Jurusan Matematika, FMIPA, Universitas Sam Ratulangi Manado. Tahun 2019 adalah tahun terakhir ia menempuh studi. Makalah ini merupakan hasil dipublikasikan penelitian skripsinya yang

Yohanes A. R. Langi (yarlangi@gmail.com)

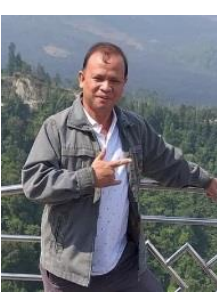

Lahir di Jakarta pada tanggal 13 Juni 1970. Pada tahun 1994 mendapatkan gelar Sarjana Sains (S.Si) yang diperoleh dari Universitas Kristen Indonesia - Tomohon. Gelar Master Sains (M.Si) diperoleh dari Institut Pertanian Bogor pada tahun 2007. Ia bekerja di UNSRAT di Program Studi Matematika sebagai pengajar akademik tetap UNSRAT.

Fernando D. Pongoh (fernando.pongoh@gmail.com)

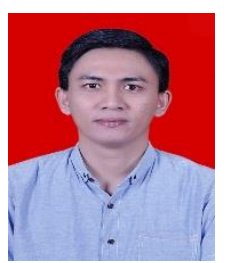

Lahir di Manado pada tanggal 23 November 1987. Pada tahun 2010, memperoleh gelar sarjana di Program Studi Matematika, Universitas Sam Ratulangi. Gelar Magister Sains diperoleh dari Institut Pertanian Bogor pada tahun 2015. Menjadi dosen di Jurusan Matematika, FMIPA, Universitas Sam Ratulangi Manado dengan bidang keahlian yang ditekuni diantaranya; Statistika, Analisis Regresi, dan Analisis Peubah Ganda. 